\title{
Kend dig selv: Om det sociale individ og det sunde samfund
}

\section{Af Regner Birkelund}

Med afsæt i en tale, som Grundtvig holdt på Marielyst Højskole i 1862, belyses i artiklen betydningen af det gamle græske oplysningsideal, Nosce Te Ipsum (Kend dig selv), der kan føres tilbage til Oraklet i Delfi, men som også var et centralt omdrejningspunkt i såvel Platons som Aristoteles' pædagogiske og samfundsmæssige tænkning. Der argumenteres for, at Grundtvig bl.a. ved at inddrage dette græske oplysningsideal i sin tale afslører en græsk side i sine tanker om livsoplysning og det samfundsmæssige fællesskab, som hidtil kun er blevet sporadisk belyst i Grundtvigforskningen. Den opfattelse, at udtrykket Kend dig selv på samme tid retter sig mod en erkendelsesakt og mod udviklingen af et medfødt etisk handlepotentiale, gøres gældende og sættes i relation til Grundtvigs begreb om menneskets gudbilledlighed.

Grundtvig var gammel af dage, da han i 1862 holdt tale på Marielyst Højskole $i$ anledning af vinterskolens åbning. Næsten 80 år var han, men mildere stemt over for sin samtids rationalistiske og latiniserede skolesystem var han ikke blevet med alderen. Med et overmåde levende og billedrigt ordvalg er hans tale i sig selv et stykke symbolik for den kamp, han forte for en langt mere levende og livsbekræftende oplysningsform end dødbideriet $\mathrm{i}$ den sorte skole, som han meget betegnende kaldte "Skolen for Døden". Under denne betegnelse regnede han uden tøven alle sin samtids skoler fra almueskolen til latinskolen og det latiniserede universitet.

I talen får Grundtvig i koncentreret form dé pædagogiske hovedpointer frem, som han i utallige skrifter og taler gennem det meste af sit liv anfægtede eller forfægtede. Grundtvig var fra et tidligt tidspunkt i sit liv blevet opmærksom på, at der var noget helt galt med den måde, oplysningen i skole og uddannelsessystemet fandt sted på. Allerede da han selv kom på latinskole i Århus, blev han klar over, at oplysning og oplysning så at sige er to forskellige ting: den rationalistiske oplysningsform, der var daglig kost i "Skolen for Døden", og så en ganske anden oplysningsform, som han kom på sporet af dels via egne erfaringer, dels via den indsigt hans historiske interesser gav ham i det gamle Grækenlands kultur og litteratur. "Skolen for Livet" og "Skolen for Døden", "Livs-Oplysning" og "Papirs-Oplysning" var de modsatrettede betegnelser, der udkrystalliserede sig for ham via hans 
egne personlige skoleerfaringer og oldgræske interesser. Disse betegnelser kom til at indgå som de helt centrale begreber i hans kamp for at reformere det danske skole- og uddannelsessystem, for den enkeltes og for samfundets skyld.

I et forsøg på at kaste nyt lys på Grundtvigs oplysningsbegreb, skal jeg i denne artikel hovedsageligt benytte mig af gammelt grcesk lys, ud fra den opfattelse, at Grundtvigs oldgræske interesse, der tog fart ved mødet med en engageret lærer på katedralskolen i Århus, var afgørende for hans oplysningsfilosofiske og samfundskritiske tanker.

\section{Det ene lys opliver, det andet slår ihjel!}

Det har været den almindelige opfattelse, at Grundtvig om sin tid på katedralskolen i Århus kun havde negativt at sige, men sådan forholder det sig faktisk ikke. Selv om han her fik indhold til begrebet "Skolen for Døden", så mødte han dog også en oplysningsform, der blev afgørende for hans visioner om "Skolen for Livet" og "LivsOplysning". I Århus stiftede han bekendtskab med to forskellige lærerskikkelser, der kom til at repræsentere de to forskellige oplysningsformer, som han bestandigt holdt op mod hinanden for at tydeliggøre sine pointer. I digtet "Gylden-Aaret" fra 1834 kommer Grundtvigs syn på den ene og den anden oplysningsform til udtryk på følgende prægnante poetiske måde:

Da skal Man Forskjel kende paa Sol-Skin og paa Lyn,

Skiønt Begge de kan brænde

og skabe klare Syn;

Thi, som Fornuften giver,

Det ene Lys opliver,

Det Andet slår ihjel!

(US VIII, 20).

Den oplivende oplysning, som Grundtvig stiftede bekendtskab med i Århus, tilskriver han konrektor Stougaard, der underviste i græsk. Stougaards store interesse for verdenshistorien, herunder den græske og nordiske mytologi, og hans mundtligt anlagte undervisning begejstrede Grundtvig. Og så var Stougaard en venlig mand, der med ægthed interesserede sig for sine elevers vel. Grundtvig skriver i en dagbogsoptegnelse fra 1802, at Stougaard havde været "sine Disciplers opdragende Fader", som han ofte tænkte tilbage på som et forbillede. Grundtvig ville, som han udtrykker det, nødig "skuffe en saadan Mands Haab og Ønsker, der kun havde reen Menneskekjærlighed til Grund, og Discipelens sande Vel til Formaal” (Albeck 1979, 52-53). 
Grundtvig skriver videre, at mindet om den "ædle Stougaard" ofte "har kaldet ham tilbage paa Dydens Vei naar han stundum - desværre havde skeiet ud fra den" (ibid., 53). Stougaard havde kort fortalt været en god og engageret lærer for sine elever, og ved sin venlige og autentiske fremtoning havde han været et menneskeligt forbillede for dem.

Mindet om rektor Krarup var noget forskelligt herfra. Om end Grundtvig hverken blev lavet til en Fux eller slået ihjel af Krarups skriftligt anlagte undervisning i latin og hebraisk, så hører denne del af bekendtskabet med katedralskolen i Århus tydeligvis til det, Grundtvig senere betegner som "Skolen for Døden". Død lærdom blev indterpet med henblik på optagelsen på teologistudiet ved universitetet $\mathrm{i}$ København. Uddannelse uden dannelse er vel slagordsagtigt det, der bedst karakteriserer Grundtvigs opfattelse af Krarups undervisning. Omvendt med Stougaards undervisning. Her var den menneskelige oplysning og dannelse - bevidst eller ubevidst - sat forrest, mens den faglige oplysning, uddannelsesdimensionen så at sige, blev et afkast af denne. Stougaards undervisning var på samme tid - som Grundtvig langt senere har udtrykt $\operatorname{det}^{1}$ - både oplivende og oplysende.

Inspireret af K. E. Løgstrup og den tale han under overskriften "Skolens formål" holdt i anledning af det daværende Danmarks Lærerhøjskoles 125 års jubilæum, kunne man også sige det på den måde, at uddannelsen - her den faglige viden og indsigt i græsk sprog, litteratur og kultur - blev "et afkast som tilværelsesoplysningen gav" (Løgstrup 1993, 47). Og det endda selv om der i Stougaards tilfælde var tale om latinskoleundervisning! Løgstrup er ganske enkelt inde på den grundtvigske og græske tanke, at skolens formål, selv i et samfund der - modsat det oldgræske - har karakter af at være et arbejdssamfund, ikke må reduceres til at være uddannelse. Formålet må af hensyn til den enkelte være langt mere ambitiøst og tage udgangspunkt $\mathrm{i}$, at livet grundlæggende har det menneskelige fællesskab både som sin forudsætning og som sit mål. At målrette undervisningen efter arbejdslivets kompetencekrav anså Løgstrup ligesom Grundtvig før ham for at være en alt for snæver målsætning. ${ }^{2}$

Af talen på Marielyst ser vi, at Grundtvig netop kritiserede, at hans samtids skoles formål i udstrakt grad var reduceret til at handle om uddannelse, i betydningen kundskabsformidling, det vil sige formidling af sådanne kundskaber, som først og fremmest er karakteriseret ved deres umiddelbare nytteværdi. Bredsiden, som Grundtvig får afleveret i talen, er dybest set rettet mod oplysningstidens alt for snævre videnskabelige oplysningsideal og tro på, at verden automatisk bliver bedre og mennesker lykkeligere i takt med, at den videnska- 
belige oplysning skrider frem. Oplysningstidens overdrevne tiltro til hvad fornuften og den videnskabelige oplysning kan udrette med og for mennesker var - sammen med sammenblandingen af kirkelige og borgerlige anliggender - den sammenhæng, hvorudfra Grundtvigs kritik blev formuleret.

\section{At loere sig selv at kende}

I skarp modsætning til en skoleform, der baserer sig på tvangsmæssig udenadslære af faktuel viden og indterpning af kristendommens læresætninger, fremhæver Grundtvig i sin tale, at det må være skolens fornemste opgave at bistå eleverne $\mathrm{i}$ den livslange proces, det er at loere sig selv at kende. Og som han udtrykker det, "faae at vide, baade hvad Menneske-Livet duer til, og hvordan de [eleverne] bedst kan bruge den Lodd og Deel, de har i Menneske-Livet, til Gavn og Glæde baade for dem selv og for hverandre" (Johansen 1956, 61). At Grundtvig i talen griber tilbage til det gamle Grækenland og det dertil knyttede oplysningsideal, Nosce Te Ipsum (Kend dig selv), som vi kender fra Oraklet i Delfi, er som antydet ingen tilfældighed. Såvel i teoretisk som i praktisk henseende havde han hos konrektor Stougaard i Århus fået en forsmag på det oldgræske oplysningsideals betydningsindhold.

Udtrykket Kend dig selv handler om at blive sig selv, at blive den man dybest set er. For grækerne var oplysning derfor ikke et spørgsmål om teoretisk (videnskabelig) vidensformidling, men i langt højere grad et spørgsmål om at udvikle de menneskelige karakteregenskaber, som gør et menneskeligt fællesskab muligt. Formålet var for grækerne menneskelig dannelse med sigte på det fællesmenneskelige etiske handlingsliv og dermed det gode samfund.

For Grundtvig drejede oplysning sig om præcis det samme. Hans tanker om oplysning og pædagogik er ligesom hans politiske og samfundsmæssige tanker i omfattende grad blevet til med inspiration fra det gamle Grækenland. Sådan fremgår det af Marielysttalen, og sådan fremgår det med tydelighed andre steder $\mathrm{i}$ hans forfatterskab. Grundtvigs graeske inspiration er vel ikke blevet overset i Grundtvigforskningen, men den er - vil jeg hævde - blevet stærkt underbetonet. Fokus har i stor udstrækning været på Grundtvigs inspiration fra Tyskland og især den, han havde fra Herder. Grundtvig havde rigtignok et omfattende kendskab til de tyske filosoffers skrifter - som jo også i et ikke uvæsentligt omfang er baseret på tankerne fra det gamle Grækenland - men han stiftede bekendtskab med Grækenland og den græske tænkning længe før, han fik den i tysk aftapning. Hans 
interesse blev vakt af en levende, verdenshistorisk tænkende og engageret lærer i græsk sprog, og denne interesse hang ved ham og intensiveredes livet igennem - både interessen for det græske sprog og for den græske filosofi og poesi.

Ikke mindst Platons skrifter har gjort indtryk på Grundtvig, uden at man af den grund kan kalde ham platoniker. Platon var på flere måder både for idealistisk og for utopisk anlagt for Grundtvig. Alligevel er der væsentlige sider af Platons tænkning, der har bidt sig fast $\mathrm{i}$ ham. Specielt Platons tanker om samtalens og det vingede ords nødvendighed i oplysningsøjemed berørte ham dybt, men også Platons statsforfatningstanker gjorde indtryk på ham, og i denne forbindelse mest af alt det forhold, at statsforfatningen er afhængig af den enkelte borgers indre forfatning. Eller sagt på en anden måde, den opfattelse, at staten ikke er bedre end de borgere, den udgøres af, var også Grundtvigs. Som Platon mente han derfor, at samfundsdannelse begynder med den enkeltes oplysning og dannelse.

Sammenhængende med fremhævelsen af samtalen som oplysningsmiddel er det en helt central pointe hos Platon, at den erkendelse, man får bibragt $\mathrm{i}$ betydningen: overtager fra en anden eller kommer til kundskab om gennem en formulering og en mening, er en afmægtig erkendelse, der ikke formår at herske i sjælen og dermed heller ikke i handlingslivet mellem mennesker. Det Platon med denne pointe sigter til, er sofisternes evne til med deres veltalenhed at besnakke deres tilhørere til at abonnere på en bestemt mening. En erkendelse af denne udvendige art, der kun lever i ord og vendinger, kan betragtes som en skjorte, man kan tage på, men som også kan skiftes ud med en anden og smartere, når en sådan byder sig. På Platons tid var der et stort udbud af sofistikerede skjorter og - kunne man fristes til at sige udbuddet er ikke blevet mindre med tiden.

Den form for erkendelse, Platon opfattede som den sande erkendelse, var af en ganske anden art end sofisternes. Den sande erkendelse lever for Platon ikke i ord, vendinger eller teorier, men ligger latent $\mathrm{i}$ sjælen og så at sige venter på at blive forløst og gjort aktiv i det etiske handlingsliv. Den sande erkendelse er med andre ord af eksistentiel art, hvorfor den da heller ikke kan doceres i betydningen: overføres fra en person til en anden; den kan allerhøjest på indirekte vis hjælpes frem af en anden. At den sande erkendelse for Platon er af eksistentiel art betyder eksempelvis, at det at erkende det gode er sammenfaldende med det at gøre det gode. Erkendelse, der ikke øver indflydelse på handlingslivet, var for Platon ganske enkelt ikke at regne for sand erkendelse. Derfor så han heller ingen mening i på sofistisk vis at holde forelæsninger for sine elever, ligesom han heller ingen tiltro 
havde til det skrevne ords evne til at forløse den sande, eksistentielle erkendelse. I dialogen "Faidros" udtrykker han sin mistillid til det skrevne ord på denne måde: "De skrevne Ord indskrænker sig til at minde den, der i Forvejen ved Besked, om de Ting, de handler om" (Høeg 1953, VI, 78). Men hvad værre var, Platon havde erfaring for, at de skrevne ord ligefrem kunne øve negativ indflydelse på eleverne. De skrevne ord

bærer sig ad som en Trompeter, der ved enhver Lejlighed kun blæser eet og samme Signal (...) og hvad angaar Visdom, da vil du kun kunne skaffe dine Elever et Skin, ingen sand Erkendelse. De faar, takket være dig, hørt en Masse Ting, men lærer ikke noget; de vil faa Skin af at have en Masse Kundskaber, skønt de paa faa Undtagelser nær er uvidende og ubehagelige at omgaas, i Besiddelse af en Skinviden, uden virkelig Visdom (ibid., 77-78).

Hvad mente Grundtvig? Ikke få er de gange, Grundtvig udtrykte sig i nedsættende vendinger om den boglige oplysningsform. "PapirsOplysning" eller "den falske Oplysning" betegnede han den med jævne mellemrum, ligesom han anvendte forskellige metaforiske variationer over det samme tema for at gøre op med tidens overdrevne tro på boglig oplysning.

Det er Folk, som skaber Bøger og ikke Bøger som skaber Folk, for i det lille Ord ligger den gyldne Lærdom, at man bliver ingenlunde et oplyst Menneske ved at læse mange Bøger, om man saa lærde dem udenad fra Ende til anden, fra først til sidst (Johansen 1956, 16).

Sådan udtrykte Grundtvig det i en Marielysttale fra 1856 og mente i klar tilslutning til Platons pointe, at den boglige lærdom ligefrem kan føre til selvklogskab og gøre mennesker "bestandig dummere paa det virkelige Menneske-Liv" (ibid., 62). Det vil sige det liv, mennesker er skabte til at leve med hinanden.

Mon ikke "den gyldne Lærdom", som Grundtvig her henviser til, skulle stamme fra Platon! I hvert fald afslører han i indledningen til Christenhedens Syvstjerne fra 1860 en vis inspiration fra Platon. Med reference til den døde boglige oplysningsform skriver han her,

at de Boglærde i vore Dage sædvanlig er saa forgabede i deres eget Bogstav-Væsen og i deres egen Papirs-Oplysning, at de ingenlunde vil give Slip paa Skriftklogskabens Pavedom, og har slet intet Øie for det virkelige Menneske-Liv i Aanden og dets uforanderlige Natur-Love, som dog allerede gamle Platon kiendte saa godt, at han maatte lee høit ved den Tanke, at nogen Aand skulde engang stræbe at forplante sit Liv og sit Lys med en Pen ( $V U$ VI, 280). 
Det levende ord i samtalen var for Platon det eneste middel, der kunne forløse den sande erkendelse i mennesket. Man kan også sige, at samtalen for Platon var den eneste vej til at loere sig selv at kende, til at frisætte det etiske handlepotentiale, der findes i ethvert menneske forud for alle refleksioner og forelæsninger over etik. Kend dig selv er på denne måde ensbetydende med at finde den sande erkendelse ved sig selv, og er derfor i dybeste forstand et spørgsmål om selverkendelse. Sokrates havde med sin jordemoderkunst lært Platon, hvordan barnet skulle forløses. Og Grundtvig lærte af Platon. Blandt andet også, at undervisning og opdragelse måtte foregå uden tvang, at det er "Lysten der driver Værket". Men Grundtvig lærte imidlertid også af den mere empirisk anlagte Aristoteles. Specielt Aristoteles' venskabsfilosofi har tydeligvis gjort et stort indtryk på ham. Ikke for ingenting havde han Aristoteles' hovedværker stående på sit bibliotek. $^{3}$

\section{Viden og venskab}

Aristoteles havde ligesom Platon den dybeste mistillid til sofisternes veltalenhed og den undervisningsmetode, de gjorde brug af. Også han mente, at sofisternes udvendige oplysning ingen positiv betydning havde for det praktiske handlingsliv. Platonisk og med slet skjult reference til sofisterne kunne han ligefrem sige, at "der er noget bagvendt ved at holde forelæsninger over etik, for formålet er ikke erkendelse, men at vi skal blive bedre mennesker" (Johansen 1993, 460). Aristoteles tilsluttede sig på denne måde den opfattelse, at oplysning og oplysning er to ting. For det første den abstrakte begrebsmæssige oplysning, den epistemiske oplysning, som ikke formår at herske i sjælen, men som der ikke desto mindre - under de rette theoretiske betingelser - kan være den største lykke og lystfølelse forbundet med. Det vil sige sådanne betingelser, hvor viden via den intuitive fornuft, nous, bliver til visdom, sophia, men så er der netop heller ikke mere tale om den sofistiske form for viden. For det andet den erfaringsbaserede oplysning, den phronétiske oplysning, der kendetegnes ved at herske i sjælen og sammenhængende hermed gennemsætter sig i det etiske handlingsliv.

Karakteristisk for Aristoteles er også det forhold, at han betragtede livets skole, hvilket vil sige livet i polis, som det bedste lærested for det etiske handlingsliv. Han mente, at det er af de erfaringer, man gør sig i det virkelige liv, man bliver klog på livet. Sandheden - men også usandheden - var for Aristoteles at finde i selve handlingslivet, i de fænomener handlingslivet på godt og ondt udgøres af. For ham var 
sandhed eller usandhed så at sige fænomenerne iboende, og handlingslivet var derfor det sted, hvor man kunne lære den gode handling at kende. Her var de bedste betingelser til stede for at realisere det etiske potentiale, som ethvert menneske ifølge Aristoteles er født med, og for at lære den gyldne middelvej i handlingslivet at kende. For Aristoteles hørte vita activa derfor med som en vigtig del af den proces, der går ud på at lære sig selv at kende. Og sådan også for Grundtvig. For ham var den ide "Løgn og Tant" som går ud på, at man kan lære sig selv at kende via abstrakt boglærdom, "da ingen kan blive klog paa Menneske-Livet uden ved at leve det”. Så kategorisk har han udtrykt det (Johansen 1956, 64). Vejen til livsklogskab og livsduelighed går så at sige over den praktiske virkelighed, mens bøgerne $\mathrm{i}$ denne forbindelse kun er at opfatte som "gode Venner i Baghaanden”, som Grundtvig har udtrykt det (Bugge 1965, 305).

Den egentlige oplysningstid begyndte ifølge Grundtvig da også først med 18 års alderen. Børn skulle have lov til at være børn og gøre deres livserfaringer i "livets skole", og almueskolen skulle omdannes til fri-skoler, men den egentlige oplysning mente han altså først kunne og burde starte ved 18 års alderen, i det han kaldte "Skolen for Livet". Hans tanker har tydeligvis rod såvel hos Platon som hos Aristoteles.

Selv om Platon tillagde vita contemplativa større betydning for det etiske handlingsliv end Aristoteles, var han dog ikke uden sans for, at vita activa udgjorde en vigtig erfarings- og oplysningskilde. Platon mente som bekendt, at det filosofiske liv tilhørte voksenalderen, netop fordi de erfaringer, som handlingslivet indebærer, er vigtige forudsætninger for det filosofiske liv. Fælles var Platon og Aristoteles også om den tanke, at oplysning er en statsopgave, og det var de ud fra den betragtning, at oplysning ikke blot er et individuelt anliggende, men et samfundsanliggende i allerdybeste forstand. Oplysning måtte godt nok have det enkelte individ som sit udgangspunkt, men det sociale individ, udviklingen af det enkelte individs medfødte potentiale til at blive samfundsborger, var selve formålet med oplysningen.

Såvel i Statslcere som i Den Nikomacheiske Etik beskæftiger Aristoteles sig med spørgsmålet om, hvordan individet bliver et socialt individ, og i denne sammenhæng er begrebet venskab et omdrejningspunkt i hans tænkning. Hvordan den enkelte sættes i stand til at leve sit liv efter den gyldne middelvejs etik og derved bliver i stand til at vinde venner, til at indgå venskaber, er det spørgsmål, Aristoteles kredser om i disse to hovedværker. Han fremholder den pointe, at det gode samfund beror på den enkeltes evne til at vinde venner, og at jo mere et samfund udvikler sig og holdes sammen som et venskabeligt samfund, des mindre er der behov for at regulere ved hjælp af love. 
Hos Platon er venskabsbegrebet ligeledes centralt. Særlig opmærksomhed giver han venskabet i dialogen "Lysis". Her ses den opfattelse, at et sandt venskab har med det gode at gøre, og at venskab beror på erkendelsen af det gode, som ethvert menneske ifølge Platon er beslægtet med. Men det står samtidig klart, at erkendelsen af det gode er sammenfaldende med det at gøre det gode (Høeg 1953, I, 201-222).

Selvom Aristoteles var mindre idealistisk anlagt end Platon, så var de dog fælles om den opfattelse, at det gode samfund er at opfatte som et venskabeligt fællesskab, der betinges af den enkelte borgers indre forfatning og i langt mindre grad af nedskrevne love. En tanke, som er gentaget hos Rousseau, der jo netop mente, at konstitutionen ikke findes i lovene, men i folkets hjerter. Det gode samfund er det samfund, hvor lovene hos lovgiveren såvel som hos den enkelte borger, "ligger gemt paa den skønneste Plads i hans Indre". Sådan formulerede Platon det $\mathrm{i}$ et af sine breve (Høeg 1953, VIII, 189). At laere sig selv at kende var derfor både for Platon og for Aristoteles ensbetydende med at lare sig selv at kende som et socialt og venskabeligt væsen og dermed som en samfundsborger.

Sådan betragtet går der en lige linie fra det gamle Grækenland og det gamle ordsprogs oprindelige græske betydning til Grundtvigs begreb om livsoplysning. Livsoplysning har grundlæggende med en eksistentiel frisættelse af menneskets etiske potentiale at gøre. Præcist som udtrykket Kend dig selv bygger det på et positivt menneskesyn, det vil sige en opfattelse af, at mennesket dybest set er godt, og at oplysning må tage sigte på at forløse dette gode og i videre forstand berede vejen for det gode venskabelige fællesskab, som den enkeltes liv og lykke afhænger af. Livsoplysning går med andre ord ud på, sagt med Grundtvigs egne ord, "at bringe Livet for Lyset og bringe Lyset ind i Livet" (Johansen 1956, 13).

Denne grundanskuelse står i skærende kontrast til den hedonistiske etikforståelse, som den fremstår hos sofisterne i Platons dialoger. Protagoras, der var den mest fremtrædende blandt sofisterne, var ophavsmand til den tanke, at mennesket er målet for alle ting, hvilket betyder, at mennesket er den suveræne herre over sin egen tilværelse og derfor netop ikke fra naturens hånd er medgivet et etisk potentiale. Mennesket er så at sige sin egen moralske lovgiver; det kan selv afgøre, hvad det vil anse for godt, og hvad det vil anse for ondt. For sofisterne fandtes så at sige intet universelt menneskeligt grundlag for etikken og derfor ej heller retningsgivende normer med universel gyldighed. Relativisme er vel den bedste betegnelse for en sådan etikforståelse. 
I stedet for normer med universel gyldighed mente sofisterne, at menneskets lystfølelse måtte være ledetråden i det etiske handlingsliv. "Det gode er lysten" var deres øverste maksime (Sløk 1978, 39). Derfor kunne de endog betragte den enevældige tyran som et etisk menneske. Tyrannen forfølger netop sin lyst og fastlægger efter sin egen målestok de normer, der skal gælde. Tyrannen er så at sige $\mathrm{i}$ stand til at realisere det sofistiske ideal om at være suveræn over livet og egenmægtig kunne fastlægge dets normer. Det var derfor intet mindre end livets eget fundament og dets moralske grundlag, sofisterne med deres veltalenhed så som deres opgave at frembringe. At lære sig selv at kende, at lære livet i sig selv at kende i dets etiske og universelle beskaffenhed var der for dem ingen mening $i$.

Det var der for Grundtvig! Med afsæt i den oldgræske tænkning og den livsanskuelse, at mennesket er skabt med et etisk potentiale, var forholdet mellem den enkelte og fællesskabet et hovedanliggende for ham. Det sociale individ var hans omdrejningspunkt, og det har med livsoplysning og livsduelighed at gøre. Livsoplysning, forstået som en fællesskabs- og samfundskonstituerende oplysning, satte Grundtvig over for den moderne oplysningsideologi, som han kritiserede for at udvikle det egoistiske individ og dermed afvikle den sociale og venskabelige dimension, som giver et samfund sammenhængskraft.

\section{Borger-Selskabet som et stort Vennelag}

At begrebet venskab og det venskabelige samfund rent faktisk var et grundlæggende tema for Grundtvig ses såvel i hans poetiske skrifter som i hans pædagogiske og samfundspolitiske skrifter, men også i hans kirkelige skrifter er dette tema nærværende. Salmen "Den signede Dag" indeholder således budskabet om det evige venskab, men det venskabsideal, der udtrykkes i salmen, kan også tolkes som et fællesskabsideal for det dennesidige liv. Sidste strofe lyder sådan:

Saa reise vi til vort Fædre-Land,

Der ligger ei Dag i Dvale,

Der stander en Borg, saa prud og grand,

Med Gammen i gyldne Sale,

Saa frydelig der, til evig Tid,

Med Venner i Lys vi Tale! (US IV, 738)

Med venner i lys vi tale - og vandre - er ganske enkelt Grundtvigs visionære tanker om oplysning og det menneskelige og folkelige fællesskab. Det folkelige fællesskab er i Grundtvigs terminologi nærmest ensbetydende med det venskabelige fællesskab, det venskabelige samfund. Klarest kommer dette samfundspolitiske ideal til 
udtryk i tidsskriftet Danskeren fra 1850. I årets første udgave skriver han den 12. januar i artiklen "Danske Nytaars-Ønsker":

Først maa jeg bede mine Læsere og Læserinder lægge Mærke til, at "Faderneland, Modersmaal og Vennelag" virkelig udtrykke alt hvad der udgiør gamle Danmark og hvormed det Danske Folks Navn og Ære, Magt og Lykke staaer og falder, medens Regierings-Form og Kongehus, Folkething og Landsthing, kirkelige, videnskabelige og borgerlige Indretninger, med alt hvad man kalder "Stat" og StatsHeelhed-Økonomi-Klogskab o.s.v. hvor vigtigt, ja, hvor godt det end ellers kan være, det er os dog kun vigtigt og godt, forsaavidt det bidrager til at værge, frede og gavne Fadernelandet, bevare, uddanne og berige Modersmaalet, vedligeholde, frigiøre, oplyse og glæde Vennelaget, som er hele Folkets Arv og Eie, Liv og Lyst, Hæder og Ære! (Danskeren III, 6).

Senere skriver han i en artikel i Danskeren om sit forhold til politiske partier med specielt henblik på Bondevennerne - som senere kom til at udgøre partiet Venstre - at "jeg vil ikke høre til noget andet politisk Parti, af hvad Navn nævnes kan, end det politiske Parti, det borgerlige Selskab og Vennelag, som det Danske Folk fra gammel Tid har udgjort" (ibid., 196). "Borger-Selskabet som et stort Vennelag" var Grundtvigs karakteristik af det, der kan kaldes et folkeligt begreb om staten (ibid, 128). Ordvalget tyder unægteligt på, at han i sin samfundstænkning og i statsforfatningsspørgsmålet har været ikke så lidt påvirket af arven fra Grækenland. Bemærkelsesværdigt er det, hvordan han som grækerne fokuserer på, at en statsforfatning må have som sit formål at skabe rammer for et samfund, der holdes sammen af venskabelige forhold, og som derfor er karakteriseret ved retfærdighed, fred og glæde.

Også i anden sammenhæng fremstår venskabsbegrebet som det helt centrale for Grundtvig. Den bygning, som hans anden kone Marie Toft lod opføre til ham i Rønnebæksholms have, kom således til at hedde Venligheden. Navnet sigter til det venskabelige forhold, der var mellem Grundtvig og Marie Toft, men har efter alt at dømme også noget at gøre med det forhold, at venskab og venlighed var omdrejningspunkt $i$ hans samfundspolitiske tænkning og samtidig indgik som et centralt tema i hans kristendomsforståelse. I den tale, han holdt ved indvielsen af havehuset i september 1854 kun to måneder efter Marie Tofts død, fremhæver han netop fænomenet venskab som en kvalitet i deres indbyrdes ægteskabelige forhold. Talen giver et godt indtryk af, hvordan venlighed som en medmenneskelig kvalitet indgår $\mathrm{i}$ hans kristendomsforståelse. Han sagde blandt andet: 
Dette Lysthus skulde dog have et Navn, og jeg har tænkt paa adskillige, som jeg dog fandt enten for indskrænkede, for døde eller for tunge at udtale, men, om jeg nu maa raade, da skal det ligesaa jævnt, som let og legende kaldes "Venligheden", og det især baade først og sidst, fordi Venligheden var Grund-Tonen og Grund-Farven i vor indbyrdes Kiærlighed! Ja, Venner, Grund-Venner, det var Marie og jeg længe før vi blev Ægtepar eller tænkde nogensinde at blive det, Grund-Venner var vi fra det første Øjeblik, vi mødtes i Verden og fik talt med hinanden, et Ægtepar med Guds Velsignelse som vi har været det, bliver vi aldrig meer, thi der, hvor hun er nu, og hvor jeg stunder hen, der hverken gives eller tages til ægte, men Grund-Venner, det bliver vi ved at være evindelig, saa Venligheden vil ogsaa være det rette Navn paa vort Værelse i den evige Bolig, som er vor himmelske Faders Huus! (Bæksted 1961, 329).

Venskab, venlighed og vennelag er udtryk, som Grundtvig igen og igen vender tilbage til, når han skriver om det ægte menneskelige fællesskab og i videre betydning det gode samfund. Også hans prædikener bærer tydelige spor af tanken om venskabet som et fællesskabsbærende fænomen. Bemærkelsesværdig i denne sammenhæng er hans tiltale af menigheden som sine venner. Allerede $\mathrm{i}$ prædikenerne fra København og Præstø fra 1821 ser vi anvendelsen af denne tiltaleform. Venskabet er så gennemgående et tema i Grundtvigs prædikener, at der ikke kan herske tvivl om, at han betragtede kirken, hvilket $\mathrm{i}$ hans forståelse var ensbetydende med menigheden, som et vennernes samfund. Og at han betragtede Jesus som vennernes ven, som det efterstræbelsesværdige men uopnåelige ideal af en ven, fremgår med tydelighed. Han er "vor bedste, vor sandeste Ven", udtrykker han i en prædiken fra 1821, idet han meget betegnende tager afsæt i Jesu ord om, at "Ingen haver større Kiærlighed, end den som sætter Livet til for sine Venner!" (GPP I, 122-128).

\section{Skabelsesmyte og livstolkning}

At Grundtvig opfattede Jesu liv og lignelser som en fortræffelig kilde til livsoplysning står uden for enhver diskussion. Alligevel mente han, at den kristelige oplysning var et anliggende for kirken, og at der her ligesom i alle andre åndelige anliggender - måtte herske fuldkommen frihed, hvilket netop ikke havde været det gennemgående træk i kristendommens historie. Kirkelig tvang og undertrykkelse havde været - og var endnu på Grundtvigs tid - dagens ret. Kristelig oplysning og den rette kristne tro var $\mathrm{i}$ århundreder blevet betragtet som den eneste vej til det gode liv. Det borgerlige og det kirkelige og "kristelige" liv var blevet sammenblandet på den uheldigste måde til 
skade for både det borgerlige samfund og for kirken. Sådan så Grundtvig på det og anfægtede den antagelse, at der ingen vej er til det sande menneskeliv uden om den kristne tro.

Han vendte rundt på denne antagelse med de så berømte ord "Menneske først og Christen saa". I disse ord ligger Grundtvigs livstolkning gemt; det vil sige det menneskesyn, på hvilket hele hans vision om livsoplysning baserer sig. Hvad går det ud på? Det går ud på, at mennesket var menneske længe før kristendommen kom ind $\mathrm{i}$ historien, at mennesket allerede i og med skabelsen og gudbilledligheden blev givet et etisk fundament for det gode medmenneskelige liv. Grundtvig anfægtede så at sige kristendommens ide om oplysning ud fra kristendommens eget grundlag, det vil sige ud fra den mosaiskkristelige skabelsesmyte og det forhold, at livet $i$ sig selv er af det gode.

Med denne mytologiske livstolkning som holdepunkt kunne Grundtvig adskille sit livsoplysningsbegreb fra det fremherskende og undertrykkende "kristelige" oplysnings-begreb. I Nordens Mythologi fra 1832 kommer hans livstolkning klarest til udtryk. Her hedder det, "at Natur-Mennesket er skabt i Guds Billede og havde i Guds LivsAande Alt hvad han behøvede til at naa sin store Bestemmelse som en Guds Søn” (US V, 401). Med afsæt i denne grundanskuelse af livet kunne Grundtvig langt senere i en Marielysttale i november 1856 udtrykke sig på følgende måde:

Selv naar vi kan og vil komme til Vorherre, enten for at finde bedre Liv eller klarere Lys hos ham, end vi selv har, saa maa vi først gaae i os selv, skyde Livet op i os og see ved det Lys, der brænder, om det er aldrig saa tyndt, saa at selv om et heelt Folk kunde og vilde blive levende og oplyste Christne, saa maatte de dog først være levende og oplyste Mennesker efter deres egne folkelige Vilkaar, ellers gik de ikke blot iblinde og vidste slet ikke hvad de sagde, men de gik igrunden slet ikke, de rørde sig slet ikke aandelig og hjertelig, men snakkede kun om det (Johansen 1956, 27-28).

Som vi ser her, går vejen til livsoplysning for Grundtvig via livet selv. Vi må derfor "gaa i os selv, skyde Livet op i os og se ved det Lys, der brænder", hvilket netop svarer til, at laere sig selv at kende. Livsoplysningens fornemste opgave er derfor at forløse det etiske potentiale, som livet $i$ sig selv er svangert med. På denne måde giver det for Grundtvig god mening at tale om, at man kan blive klog på sig selv, men også at alle uanset folkelig herkomst dybest set rummer det samme fællesmenneskelige potentiale. Et fællesmenneskeligt potentiale, hvis udfoldelse forskellige religioner såvel som pædagogiske og 
politiske ideologier i bedste fald har fremmet, i værste fald har hæmmet.

At den sande erkendelse for Grundtvig som for Platon er af eksistentiel art ses tydeligt derved, at Grundtvig fremhæver, at den erkendelse, vi blot har i ordene som fornuftsmæssig erkendelse, ikke er den sande erkendelse. Kun den erkendelse, som sætter sig igennem i handlingslivet som livsduelighed, er for Grundtvig sand erkendelse. Om erkendelse fører til livsduelighed, beror efter Grundtvigs overbevisning på, om den er af "aandelig og hjertelig" karakter, om den er rodfæstet i følelsen eller ej. Nok så flotte idealer og teoretisk viden gør det ikke!

Det er denne eksistentielle erkendelsesdimension, der ligger til grund for det udsagn - der bedre end noget andet - sammenfatter Grundtvigs erkendelsesteori, nemlig udsagnet: "Forstand paa Livet er slet intet Andet end en Følelse hos os, der kommer for Lyset og bliver sig selv klar" (GSkv II, 99). En følelsernes erkendelsesteori, som Grundtvig ikke mindst formulerede som en korrektion af Kants og dermed modernitetens rationalistiske erkendelsesteori.

Længe før Heidegger gjorde op med Kants transcendentalfilosofiske erkendelsesteori og vendte rundt på forholdet mellem det erkendende og det eksisterende menneske, havde Grundtvig sagt, "at hos os Mennesker gaaer Livet altid foran Lyset" (GSkv II, 254), og derfor mente han, at det var rent galt, "i den menneskelige Udvikling ikke at ville lade sig lære og lede af Menneske-Naturen og MenneskeErfaringen, men at ville med Vold og Magt nøde dem til at modsige, fornægte og kuldkaste sig selv" (ibid.). Til volds- og magtudøverne regnede Grundtvig som tidligere antydet både den undertrykkende skole og den undertrykkende kirke.

Livsoplysning kunne for Grundtvig aldrig komme i stand ved brug af vold og magt, men derimod som en frugt af den frihed, der kendetegner ægte samtale og ægte samvær. Ingen kan ifølge livsoplysningens rationalitet tvinges til livsoplysning. Den er, som Grundtvig har udtrykt det, "Enhvers egen Sag og er sin egen Belønning" (ibid., 116). Derfor duer uddannelsesteknologi og mål-middelpædagogik heller ikke i denne sammenhæng. Det betyder imidlertid ikke, at livsoplysning ikke kan forenes med faglighed. Livsoplysning og faglighed er ikke hinandens modsætninger, men altafgørende er de betingelser, undervisningen gives, og her er ikke mindst lærerens frihed og personlighed et væsentligt aspekt. Det var det, Grundtvig var inde på, da han henviste til konrektor Stougaard som et venligt og menneskeligt forbillede for sine elever. Selv midt i latinskolen i Århus kunne den faglige undervisning føre til livsoplysning! 
Spørgsmålet er, om ikke alle fag under de rette betingelser, hertil regnet de muligheder lærerne gives, kan gøres til højskolefag og medføre livsoplysning? Et faktum er det i hvert fald, at Grundtvig selv foreslog, at skolen i Soer skulle kunne rumme alle mulige fag, herunder også fremmedsprog og matematik. Men til de rette betingelser hørte som et ufravigeligt krav, at undervisningen måtte forbindes med samtale og fri modtagelighed, hvilket bl.a. betød et farvel til den sorte skoles eksamenstyranni.

Til livsoplysningens rationalitet hører også den romantisk inspirerede tanke, at "det nytteløse er det nyttigste". En tanke som i øvrigt kan føres tilbage til såvel Platon som Aristoteles. De var enige om, at de unyttige fag er de mest karakterdannende. ${ }^{4}$ I Statslcere er Aristoteles således inde på sangens og musikkens betydning for den etiske del af sjælen. "Sangen er den største glæde for de dødelige", skriver han i denne etiske sammenhæng (Aristoteles 1999, 349). Med sangen er dagen "godt begyndt og halv fuldendt", skrev Grundtvig (GSkv II, 244), idet også han tillagde den glæde, som sangen formidler, den største værdi som et etisk bærende livsfænomen. Med venner $i$ lys vi tale - og vandre, var Grundtvigs vision om det gode samfund, og til denne vision er gladen knyttet som et samfundskonstituerende fænomen.

Ikke alene tanken om "Skolen for Livet" og udviklingen af et venskabeligt samfund er en arv fra det gamle Grækenland. Også Grundtvigs negative syn på demokrati som forfatningsform stammer herfra. Paradoksalt er det, at vi i dag ynder at fremhæve Grækenland som det vestlige demokratis hjemland. De gamle græske tænkere, herunder Platon og Aristoteles, betragtede selv demokratiet som en forfatningsmæssig afart. Et pøblens diktatur. Belært af grækerne kunne Grundtvig derfor heller ikke betragte demokratiet som en efterstræbelsesværdig forfatningsform. Demokrati behøvede efter hans opfattelse overhovedet ikke at være forbundet med noget folkeligt.

I stedet for demokrati var han en varm fortaler for det, han kaldte agte folkestyre, men en forudsætning for folkestyre var det efter hans opfattelse, at almuen såvel som de privilegerede stænder blev oplyst på en sådan måde, at den ekskluderende standsbevidsthed blev omformet til en fælles folkebevidsthed. Derfor var der for Grundtvig god mening $i$ at tale om folkelig livsoplysning som det middel, der skulle gøre et ægte folkestyre muligt; det vil sige en forfatningsform, der baserer sig på det faelles bedste som sin grundlov. Men hvis denne grundlov ikke er integreret $\mathrm{i}$ den enkelte borger som solidaritetsfølelse og samfundssind, så mangler den del, der ifølge Grundtvigs samfundstanker skal holde det hele sammen. Har den enkelte borger kun sig selv og sine 
egne snævre egoistiske interesser som sit omdrejningspunkt, ja, så er der tale om et samfund under opløsning. Så vil resultatet let blive, at det folkestyre, som vi har kaldt demokrati, ender i ufolkelighed i alles kamp mod alle, hvor det i stedet med Grundtvigs ord skulle have været en fælles kamp for et folkeligt og venskabeligt fællesskab.

\section{Afsluttende bemorkninger}

Selvom vi vel endnu kan bryste os af at være borgere i et af de bedste samfund i verden, så er der god grund til at erindre om, at demokrati i den folkelige udgave ikke er kommet til os en gang for alle, men er noget, hver enkelt generation må kæmpe for og oplyses til. Udviklingen af et folkeligt demokrati er et langtidsprojekt. Det lader sig ikke gøre med snuptagsløsninger og ej heller med vold og magt. Det har historien fremvist mange eksempler på.

Demokrati forstået som folkestyre er dybt afhængigt af den enkelte borgers indre forfatning. Det er, når alt kommer til alt, den enkelte borgers indre forfatning, der bestemmer om demokratiet skal blive til en samlivsform mere end blot en styreform. Sagt på en anden måde, det er de enkelte borgeres sindelag, der afgør, om demokratiet bliver en samfundsform eller blot en statsform. At være samfundsborger er noget andet og mere end blot at være statsborger.

Grundtvigs tanker om livsoplysning rummer i dette samfundsmæssige perspektiv en særdeles kraftig, men nødvendig kritik af den omsiggribende uddannelsesteknologi, som bygger på den grundidé, at vi kan organisere al undervisning som en produktionsproces med dertilhørende produktevalueringer, kvalitetssikring og kvalitetskontrol som midler til øget effektivitet og produktivitet. Den uddannelsesteknologiske fremmarch truer med at tilintetgøre Grundtvigs pædagogiske og samfundsmæssige visioner, og det gør den paradoksalt nok ved at kaste arvesølvet fra det antikke Grækenland, som vi ynder at forbinde vores demokratiske samfundsindretning med, over bord.

Med afsæt i den uddannelsesteknologiske ideologi er man godt i gang med at afvikle den institution, som hele det øvrige uddannelsessystem kunne hente inspiration fra, fordi den netop er skabt ud fra en overbevisning om, at dannelse og uddannelse ikke behøver at være hinandens modsætninger - men alt for ofte har været det. Der ses tendenser i tiden til at den folkelige højskole, som en af de få tilbageblevne repræsentanter for ideen om "Skolen for Livet", hvor menneskelig dannelse og livsoplysning - og ikke blot viden og kompetencer - er det centrale, er ved at blive aflivet. Af hvem? Af den 
selv samme uddannelsesteknologiske ideologi, som den folkelige højskole blev skabt i et opgør med og som et alternativ til.

Aflives denne oplysningstradition, mister vi et rum, der burde holdes fri af den moderne kompetencejagt, et rum og en tradition, der burde holdes levende som inspirationskilde til fornyelse af det moderne samfund, som meget vel med uddannelsesteknologiens mellemkomst kan gå hen og blive både ufolkelig og umenneskelig. "Statsborgere" og ikke egentlige samfundsborgere med solidaritets- og fællesskabsfølelse kan blive det samfundsopløsende resultat. Anderledes udtrykt: med den uddannelsesteknologiske ideologi som drivkraft for udviklingen af et samfund med materiel rigdom kan vi komme for skade at udvikle et samfund, der lider af åndelig fattigdom. Nogle vil mene, at det allerede er sket! Nogle mener endda, at den tilpasningspædagogik, der forbinder sig med den uddannelsesteknologiske ideologi, og som påberåber sig så tilsyneladende uantastelige værdier som bl.a. omstillingsparathed og fleksibilitet, producerer individer med psykopatiske træk. ${ }^{5} \mathrm{Og}$ det er alt andet end samfundsborgere! Holdningsløshed og samvittighedsløshed, upålidelighed, uærlighed og egoisme spøger i baggrunden som samfundsopløsende fænomener.

Uddannelse og oplysning er i allerdybeste forstand et samfundsanliggende og er derfor også en samfundsopgave. Måden, hvorpå denne opgave gribes an, har den største betydning for, hvilket samfund vi får. Sådan så Grundtvig på det, og sådan så de gamle grækere på det.

Det sunde, venskabelige samfund opstår ikke af sig selv, men må til stadighed udvikles og næres via menneskelig oplysning og dannelse, og i denne forbindelse er det nødvendigt - skal vi tro de gamle grækere og den grceske Grundtvig - at modarbejde den omsiggribende uddannelsesteknologiske udvikling og holde fast $i$, at det væsentligste er at udvikle den menneskelige karakter frem for karakterer, ${ }^{6}$ og at det nytteløse, det, der ikke umiddelbart fører målelige kompetencer med sig, i denne sammenhæng er af største betydning. Glæden og livsmodet, som sangen og andre æstetiske udtryk formidler, er etiske bærende livsfænomener og hører til de bedste kendetegn på et sundt samfund.

\section{Forkortelser}

Danskeren I-IV: N. F. S. Grundtvig (1848-51), Danskeren, et Ugeblad, bind 1-4, København.

GPP I-II: Chr. Thodberg (udg.) (1988), Grundtvigs Prastøprcedikener 1821-22, bind 1-2, København. 
GSkv I-II: K. E. Bugge (1968), Grundtvigs skoleverden i tekster og udkast, bind 1-2, København.

Nordens Mythologi: N. F. S. Grundtvig (1832), Nordens Mythologi eller Sindbilled-Sprog - Historisk-Poetisk udviklet og oplyst af N. F. S. Grundtvig, København.

US I-X: Holger Begtrup (udg.) (1904-09), Nik. Fred. Sev. Grundtvigs Udvalgte Skrifter, bind 1-10, København.

$V U$ I-X: Georg Christensen og Hal Koch (udg.) (1944), N. F. S. Grundtvigs Varker i Udvalg, bind 1-10, København.

\section{Litteraturliste}

\section{Værker af Grundtvig}

Albeck, Gustav (1979), N. F. S. Grundtvigs Dags-og Udtogsbøger, bind 1-2, København.

Begtrup, Holger (udg.) (1904-09), Nik. Fred. Sev. Grundtvigs Udvalgte Skrifter, bind 1-10, København.

Bugge, K. E. og Vilhelm Nielsen (udg.) (1983), N. F. S. Grundtvig 1834, Statsmoessig Oplysning: et udkast om samfund og skole, København.

Grundtvig, N. F. S. (1832), Nordens Mythologi eller Sindbilled-Sprog - Historisk-Poetisk udviklet og oplyst af N. F. S. Grundtvig, København.

_ (1847), "Skolen for Livet og Academiet i Soer" i GSkv II, 79-125.

- (1847), "Lykønskning til Danmark med Det Danske Dummerhoved og Den Danske Høiskole" i GSkv II, 210-267.

- (1848-51), Danskeren, et Ugeblad, bind 1-4, København.

— (1860), "Christenhedens Syvstjerne" i VU VI, 274-390.

Johansen, Steen (udg.) (1956), N. F. S. Grundtvig, Taler paa Marielyst Højskole 1856 - 71, København.

Thodberg, Chr. (udg.) (1988), Grundtvigs Prcestøprcedikener 1821-22, bind 1-2, København.

\section{Værker af andre forfattere}

Aristoteles, Statslcere. Oversat af William Norvin og Peter Fuglsang (1999), København.

Aristoteles, Den Nikomacheiske Etik, Oversat af Niels Møller, rev. af Peter Thielst (1995), Frederiksberg.

Birkelund, Regner (1999), Livsoplysning, København.

Bugge, K. E. (1965), Skolen for Livet, København. 
Bæksted, Anders (1961), “Omkring 'Venligheden' - Grundtvigs sommerhus på Rønnebæksholm” i Historisk Samfund for Prcestø Amt, Årbog, 293-380.

Folkehøjskolens Sangbog, 17. udg.

Høeg, Carsten og Hans Ræder (udg.) (1953), "Breve" i Platons Skrifter, bind 8, København, 135-209.

Høeg, Carsten og Hans Ræder (udg.) (1953), "Faidros" i Platons Skrifter, bind 6, København, 15-88.

Johansen, Karsten Friis (1988), Platons filosofi - udvikling og enhed, København.

Johansen, Karsten Friis (1993), Den europceiske filosofis historie, Antikken, bind 1, København.

Løgstrup, K. E. (1961), "Højskolens nye fronter" i Johannes Rosendahl (red.), Højskolen til debat, København, 203-216.

Løgstrup, K. E. (1993), "Skolens formål” (1981) i Solidaritet og Karlighed og andre essays, 2. udgave, København, 44-56.

Slang, Tine Elisabeth (2004), Danning i skiftende epoker, Hovedopgave i pedagogikk, Høgskolen i Lillehammer (upubliceret).

Sløk, Johannes (1978), Platon, København.

Noter

1 Sådan udtrykker Grundtvig sig i artiklen "Om almindelig Oplysning” i Danskeren 1848, 572.

2 At Løgstrup ikke er uden inspiration fra Grundtvig og den folkelige livsoplysningstanke, fremgår af artiklen "Højskolens nye fronter" (Løgstrup 1961).

3 Se Fortegnelse over den af N. F. S. Grundtvigs efterladte Bogsamling, København 1873.

4 Se eksempelvis herom i Johansen 1993, 489.

5 Under overskriften "Det moderne samfund fremelsker psykopater" udtaler psykolog Bo Møhl, Rigshospitalets Psykiatriske Klinik, at det moderne samfund, hvor enhver er sig selv nærmest, fremmer psykopatisk adfærd (Kristeligt Dagblad, 23. april 2004).

6 Denne vending er jeg blevet inspireret til via Tine Elisabeth Slangs hovedopgave i pædagogik fra Høgskolen i Lillehammer 2004. 